\title{
Ireland: revolt against property tax robbery
}

cross Europe we have seen what austerity really means - the blatant robbery of working class people. After the attempted raiding of bank accounts of Cypriot workers and the onslaught of austerity in Portugal after previous measures were deemed unconstitutional, working class people in Ireland face the prospect of the robbery of a 'property tax' from their wages, social welfare payments or pension. The Government is threatening that those that have not signed up to pay the tax can have it forcibly deducted from 1 st July 2013.

This move, to give the Revenue the power to collect the tax, is partly due to the success of the massive non-payment campaign against the household tax last year organised by the Campaign Against Home and Water Taxes (www.nohometax.com). Despite massive propaganda,

scaremongering and fear, a majority of single home owners refused to pay that tax, which was $€ 100$ for every home in the country. Hundreds of meetings were organised across the country, which tens of thousands attended.

In response, the Government passed responsibility to collecting it to the Revenue Collectors. In addition, it has been transformed into a property tax that was demanded by the Troika as part of the so-called bailout deal. This is a tax of 0.18 per cent of the value of residential property. This is not a tax on the wealth of the rich but on working people's homes.

Despite the propaganda, these are not taxes to fund or improve local public services. In fact, the funds for local public services are being cut. Instead, this is a bailout tax, pure and simple. The money will go to fund what is, relatively speaking, the world's largest bankbailout. While the property tax is supposed to yield $€ 500$ million, $€ 26$ billion in taxpayers' money will be handed over to the bondholders this year - between payments on the national debt and payments by the bailed-out banks.

The anger against the property tax and the household tax are not simply about the unjust taxes themselves. They have become a lightning rod for opposition to the politics of austerity and bank bailouts generally. In the face of a Trade Union leadership that has failed to lead any fight back, the Campaign Against Home and Water Taxes has become an important vehicle by which people can respond.

The strategy of the campaign is to maintain the boycott, encouraging people not to register by the deadline of the end of May 2013. According to an opinion poll, 29 per cent of people plan not to pay. This year, however, the campaign is emphasising, that non-registration alone is not enough, because of the power of the Revenue to deduct the tax. Therefore it has to be matched with a massive campaign of protest and political pressure to make it very difficult for the Government to take the political decision to forcibly deduct the tax.

The context for this struggle is the weak nature of the Government and the vulnerable position of the Labour Party component in it in particular. The Government is a coalition between the traditionally right-wing Fine Gael and supposedly socialdemocratic Labour Party. In a recent by-election, Labour was humiliated, with its vote going from 10,000 to less than 1,000 votes. It has been weakened by defections and it faces a wipe out in next year's local and European elections because of its slavish implementation of Troika diktats.

The strategy of the campaign now is to pile the pressure on. We need the largest possible boycott for this and the campaign should be linked to the growing fight against cuts and attacks in the trade unions, as seen with the rejection of a new pay-cutting deal for the public sector which was advocated by the majority of Trade Union leaders. The No vote to this deal was a clear vote against austerity.

The recent conference of the Campaign agreed that local campaigns should now discuss standing anti-home tax and antiausterity candidates in the 2014 local elections. It is a method which can be used to force Labour to think twice about deducting the property tax from people's wages and welfare.

A turning point is being reached in Ireland, whereby people can simply take no more.

Paul Murphy - Socialist Party

Member of the European Parliament representing Dublin

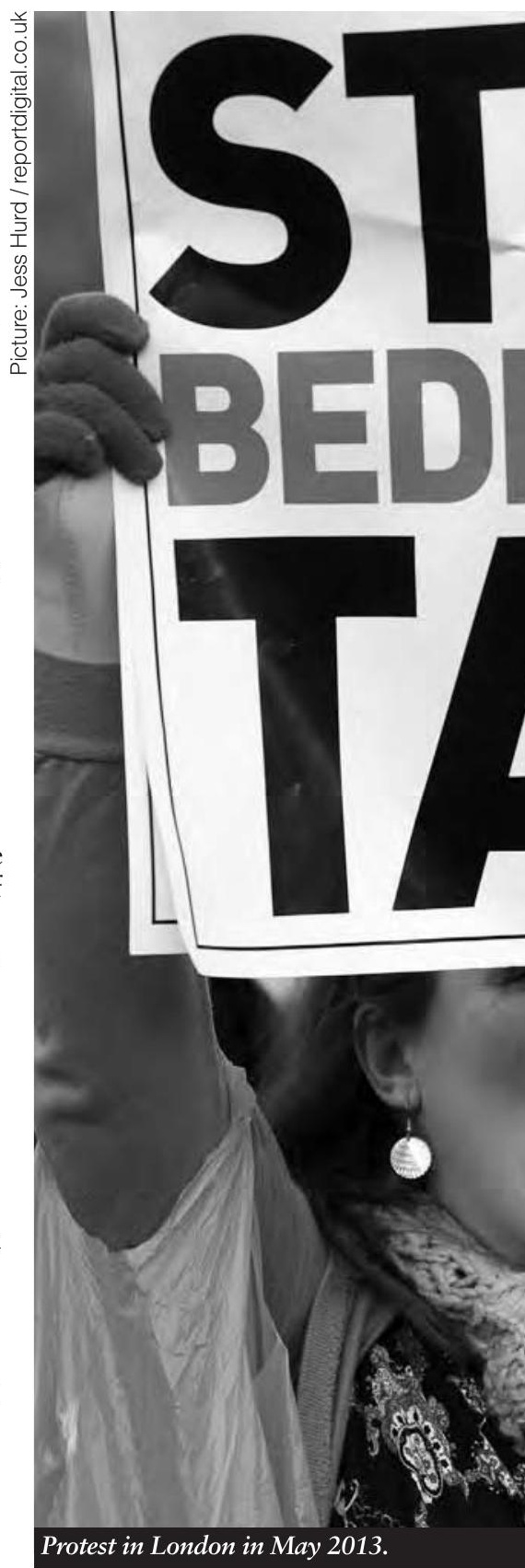

\section{April}

11: The chief executive of Stobart Group, the trucking group and rumoured future of legal services, is to go on trial for contempt after a whistleblower won part of a High Court case against him and the group's legal director. A judge ruled that Andrew Tinkler and Trevor Howarth may have lied in order to silence a whistleblower.
14: Chris Grayling MP continues to pander to the Tory backbenches as he announces that prisoners are to have a number of 'perks' removed. Grayling wants to stop prisoners using games consoles and watching Sky Television as well as requiring them to wear uniforms rather than their own clothes.
21: A Brazilian court sentences 23 police officer to 156 years in prison each for their role in the killing of 111 inmates during the prison uprising at Carandiru in 1992. Three officers were acquitted and more are to stand trial in the months ahead.
22: Barristers and solicitors in the north west of England hold an all-day meeting to discuss the Government's plans to reform legal aid. The de facto strike saw a few hundred barristers meet in a hotel in Manchester to debate the proposals. A spokesman for those involved said the 'turnout demonstrates the strength of feeling across the criminal bar. There is a sense of unity within the room'. 